\title{
Covid-19 Impact: Indonesia Tourism in New Normal Era
}

\author{
Eddy Guridno, Aberar Guridno
}

\begin{abstract}
This study examines the problem of the impact of Covid-19 on the Tourism Industry in the New Normal Era, which is a previously unusual or unfamiliar situation which is then made into a standard of habit or expectation. This research is expected to be able to further explain the impact of Pandemic Covid-19 on the tourism industry which must recover immediately from the slump in Post Covid-19 or in the New Normal Era, able to explain where the tourism industry is going, how governance and how the tourism industry will be able to adapt with the dramatic restructuring of the economic and social order in business and society. The method in this research is a qualitative method with case studies to describe the complete picture of the events under study. Data obtained from various sources, documents, and other written data. The findings of this study explain that all components of the tourism industry both government, hospitality, travel businesses, tourism objects and various other supporting institutions as a whole must be able to have protocols as a standard that must be adhered to in providing services and services in all sectors of the tourism industry. Meanwhile the governance of the tourism industry must be able to optimize marketing strategies by making full use of the various advantages of information communication technology that will be very dominant in all sectors of activity which will thus be able to adapt to various global economic and business restructuring.

Keywords: Covid-19 Pandemic, Tourism Industry, Marketing, New Normal Era
\end{abstract}

\section{INTRODUCTION}

The Covid-19 pandemic also has a large impact on the Indonesian economy. Indonesia, known as an archipelago, is made Indonesia famous for its tourism sector. The tourism sector has a short-term and long-term impact on the Indonesian economy. Short-term impacts can be felt directly, while long-term impacts can be seen by increasing national income. After the existence of Covid-19, the tourism sector is now experiencing sluggishness so that purchasing power has decreased dramatically due to reduced visitors both local and foreign tourists, which automatically generated income and foreign exchange generated from the tourism sector. Other types of companies also felt the effects of the Covid-19 pandemic. Activities that are usually carried out outside the house directly now are forced to be done inside the house. And there are also many employees who are threatened with termination of employment rights (layoffs) because many

Revised Manuscript Received on July 15, 2020.

* Correspondence Author

Dr. Eddy Guridno, S. E., M. Si. M., Assistant Professor, National University, Jakarta, Indonesia.

Aberar Guridno, M. AP., Secretary of Professional Development Board, National University, Jakarta, Indonesia.

(C) The Authors. Published by Blue Eyes Intelligence Engineering and Sciences Publication (BEIESP). This is an open access article under the CC BY-NC-ND license (http://creativecommons.org/licenses/by-nc-nd/4.0/) jobs do not allow to be done at home, such as production activities that depend on machines that are on the production site. The corona virus outbreak that began in late 2019 in Wuhan, China has now spread throughout the world. As of the end of May 2020, the corona virus had infected 213 countries with more than $6,452,391$ people. Some countries then shut down entry and exit access (lockdown) to prevent more widespread transmission. This of course greatly reduces population mobility which greatly impacts the economic performance of a region. One of the affected industries is the tourism industry. As an industry based on the mobility of people, the corona virus outbreak directly hit the tourism industry. The number of economic sectors in the tourism industry causes the impact of the decline in the tourism industry not only limited to sectors related to tourist travel and accommodation.

Several other supporting sectors of tourism activities were affected. Given the ability of the spread of the corona virus is very rapid, causing steps to restore the tourism industry is not the right choice. Therefore, in anticipation of the decline in tourism activities it is necessary to adapt to various components of the tourism industry both in the production, marketing and service processes.

Many studies have been conducted in examining the impact of tourism activities on the economy. Stynes (1999) has developed a method of analyzing the calculation of the impact of tourism activities on the economy of tourist shopping based. Kreishan (2015) uses an econometric approach to examine the relationship between tourism development and economic growth in Bahrain. Awirya (2009) examines the impact of tourism activities on the Balinese economy. On the aspect of the impact of a decline in tourism activities on the economy, Steiner et al (2012) examined the impact of a decline in tourism activities on the poor. However, there are still not many studies on the impact of Covid-19 on the Tourism Industry in the New Normal Era.

\section{RESEARCH METHODS}

This research uses a qualitative approach. Qualitative research approach is interpreted by Nashid Golafshani as research that uses a natural approach (natural approach) with the aim to understand the phenomena studied in the context of a specific setting. He quoted the statements of Jean Claude Levi-Strauss and Henry Corbin, that qualitative research are forms of studying phenomena that cannot be studied through quantitative research.

Published By:

Blue Eyes Intelligence Engineering and Sciences Publication 


\section{Covid-19 Impact: Indonesia Tourism in New Normal Era}

This research uses a qualitative approach. Qualitative research approach is interpreted by Nashid Golafshani as a study that uses a natural approach (natural approach) with the aim of understanding the phenomena studied in the context of a specific setting, that qualitative research is forms of studying phenomena that cannot be studied through quantitative research.

This research method uses a qualitative approach. Qualitative research approaches are not used in measuring large, how much, (number problems). The task of qualitative research is to reveal the things that are happening behind the phenomenon in the form of why, and how. Jensen and Jankowski, said that qualitative analysis focuses on measuring the object analyzed in relation to a particular context, in contrast to quantitative research that is general in nature. Qualitative methods can also be defined as qualities that refer to what, how, when, and where the meaning of the thing under study. Qualitative research then refers to the meaning, concept, and definition, characteristics, metaphors, symbols and descriptions of something.

John W. Creswell called the qualitative approach an attempt by the researcher to develop interpretations that claim knowledge. He added, the qualitative approach emphasizes the behavior of the object under study.

Creswell quotes Denzin and Lincoln (2005),

"Qualitative research is a situated activity that locates the observer in the world. It consists of sets of interpretive, material practices that make the world visible. The practices transform the world. They turn the world into a series of representations, including field notes, interviews, conversations, photographs, recordings, and memos of the self. At this level, qualitative research involves an interpretive, naturalistic approach to the world. This means that settings, attempting to make sense of, or interpret, phenomena in terms of the meaning people bring to them. "

From this quote, it is known that qualitative research is characterized by the interpretation (interpretation) of the researcher in investigating cases of certain phenomena in their natural environment. Investigations conducted by researchers are not merely in the form of collecting raw data, but are accompanied by an interpretation of the data obtained, so that the data is meaningful in compiling a series of stories about the phenomenon being investigated.

The data used as a source of qualitative research there are many kinds. At least the diversity of data in the form of field notes (eye reports), interviews, conversations with other parties in the study, photo documents, recordings (both interview records and others), and the memo notes of the researcher.

Qualitative research approaches are divided into several forms (sub-approaches): (1) ethnographic studies, (2) grounded theory research, (3) case studies, (4) phenomenological research, and (5) narrative research. This research uses a case study sub-approach. This research will use case studies as a sub-approach in studying the object being studied.

The Case studiy is qualitative research approaches in examining a specific set of cases tied to a particular system framework.. A case study is a qualitative approach by looking at a phenomenon that is examined in a variety of time qualitative researchers study things in the natural

periods, in detail, collecting in-depth data, including using multiple sources of information (observation, interviews, audio-visual material, documents and reports), based on a specific theme (point of view) in the review.

"I choose to view it as a methodology, a type of design in qualitative research, or an object of study, as well as a product of the inquiry. Case study research is a qualitative approach in which the investigator explores a bounded system (a case) or multiple bounded systems (cases) over time, through detailed, in-depth data collection involving multiple sources of information (e.g., observations, interviews, audiovisual material, and documents and reports), and reports a case description and case-based themes. For example, several programs (a multi-site study) or a single program (a within-site study) may be selected for study."

This research activity is in the form of examining one particular case, can be in a span of time (a certain time point), can be with a certain period of time that is longer (long period). In the context of time, this study makes the time from January 2020 to May 2020. That time was used considering that January 2020 was the beginning of the stipulation as Covid Pandemic -19 until the end of May 2020 research.

The relevant theories are used in this study. A qualitative research approach uses theory as a broad explanation of the behavior of the actors being studied, as a perspective lens in seeing the phenomenon being studied, and being a reference at the end of the research conclusions. One function of theory, as an explanatory tool, by Lather is as a reciprocal relationship between data and theory. According to Lather, data must make it possible to build propositions in dialectical forms, on the one hand linked to theoretical frameworks (theories used in research) a priori, also on the other hand to maintain a particular framework (cases that are studied) based on the data collected findings, and theory is also used as a container where the data findings can be arranged into a series. In this study, the used theories are tasked with looking at the relationship between data from one another, and aims to reach reciprocal conclusions between the data set with the theories used.

\section{RESULTS AND DISCUSSION}

Various tourism destinations are believed to be full of face-to-face meetings between employees and tourists, therefore internal marketing is very relevant to be implemented. In various descriptions Kotler and Hermawan (2017) find several steps in the development of internal marketing, namely, (1) Forming a team that fits the task as internal marketing, (2) Evaluating the strengths and weaknesses of internal marketing, (3) Aligning internal marketing strategies with marketing external, (4) Delivering internal marketing to all employees through internal media, and, (5) Receiving input from all employees to improve internal marketing. Equally important are the benefits of internal marketing, namely (1) reducing the circulation of human resources, (2) providing quality services to external customers, (3) increasing the brand consistently.

Published By:

Blue Eyes Intelligence Engineering and Sciences Publication 
This matter can be in the management of good tourism objects can be realized if the tourism object management will consistently create a healthy organizational culture.

Thus the purpose of internal marketing is not solely for the benefit of the company, but it is very important to deliver excellent service to tourists.

Business competition, including in the tourism industry, is increasingly stringent for that excellent service can be used as a competitive advantage that will be able to create a reputation, as a strategy to build long-term sustainable relationships with tourists. Zang et al. (2008) suggested that a positive reputation of a tourist destination will reduce the risk of inconvenience to the traveling experience.

Meanwhile Morgan et al. (2011) convey the reputation of a good tourist attraction will increase high competitiveness. The research proves that internal marketing can create a positive reputation and increase the competitiveness of tourism destinations. Then how about the management of attractions to implement internal marketing as part of a marketing strategy.

Brand repositioning is one of the strategies that can be used by the tourism industry, due to drastic and significant changes in tourist behavior as a result of the Covid-19 Pandemic. In any new normal conditions related to health, consideration of tourists in determining the choice of products and services offered by the tourism industry. This change in tourist behavior requires brand repositioning carried out by delivering new value promises of new products that must be designed properly according to the demands and tastes of tourists, so as to be able to provide a pleasant experience for tourists, and this will be a differentiator which will be the reason why tourists choose the products and services offered compared to other products offered by competitors.

In this connection the delivery of values will be a strategic step that determines the success of the tourism industry. Lanning and Michaels (1988) in Tonny Hendratono (2020) suggested three steps in the value delivery system, namely, (1) Selecting value, (2) Preparing value, and (3) communicating value to customers. In an effort to select and prepare values, the company's attention is focused on customers rather than competitors. As said Ohmae (1988) If only concerned with competitors, companies only compete with competing product features, which are not necessarily true and important for customers. Therefore the promise of new values should focus on tourism products that are really needed and desired by tourists, so that tourists are satisfied and will be loyal. However, we must pay close attention to how to deliver the promise of new values in the new era of normalcy. Among them can use brand communication to inform, remind, and persuade (persuasion) tourists to always use the products and services offered by optimizing cooperation in the use of various online media such as market places, and various social and offline media such as newspapers, television, radio, exhibitions , banners, posters, brochures and flayers can even do a combination of online and offline media.

The right brand communication strategy can be expected to encourage tourists to have the right information awareness in determining the choice of tourism products that suit their desires, so that they will get a pleasant experience and foster an attitude of loyalty. In Tonny Hendratono (2020), several studies that prove brand communication can be used to create cleanliness, comfort, and safety will be the main

brand loyalty. Brand communication aims to increase brand loyalty by strengthening customer relationships with the brand from time to time where brand communication has a significant role in creating a positive brand attitude. Positive brand attitude such as brand trust and brand loyalty is very important for long-term brand sustainability.

Indeed, the existence of the Covid-19 Pandemic which has not been completed to date is the main reason that the Indonesian tourism industry is losing momentum to grow and develop in 2020, as a result of the Covid-19 Pandemic. All indicators related to tourism experienced a very significant decline such as foreign exchange earnings, the number of tourist visits both foreign and domestic, a decline in the value of exports and the contribution of tourism to GDP. But a glimmer of hope began to appear in the middle of 2020, when several countries began to open themselves from the lock down, so did the Indonesian government begin to loosen PSBB in some areas. This condition provides fresh air for the life of the tourism industry. As the results of Alyara's research (2020) in Tonny Hendratono (2020) found 21\% stated traveling as the most desirable activity after the Covid-19 Pandemic was completed. It is expected that in the Post-Pandemic Covid-19 with the emergence of the new normal era will have a positive impact on various tourism objects, so that it can trigger a re-growth and development of the Indonesian tourism industry.

But in the new normal era, the pattern of traveling will experience a very significant and drastic change, something that was never done before, now will become an obligation and even new habits that will be carried out in a tour. The behavior of tourists will experience changes, especially related to aspects of health, safety and cleanliness in making decisions for travel.

Management of tourism destinations needs to pay close attention to new phenomena, to provide a sense of comfort for tourists, so as to provide a pleasant experience for tourists. Tourist disappointment can cause losses and even bankruptcy in tourism destinations. Alegre and Cladera (2006) convey the results of their research that customer loyalty to tourism destinations is highly dependent on satisfaction when getting a pleasant experience when traveling.

Morrison (2010) defines tourist behavior is how tourists choose, consume and act after consuming services in the hospitality and travel industries. There are two factors that influence it, personal and interpersonal. Personal factors include needs, desires, motivations, perceptions, learning, personality, lifestyle and self-concept. While interpersonal factors include culture, reference groups, social classes, leadership and family opinions. While Armstrong, Kotler and Silva (2006) find factors that influence purchasing behavior are environmental conditions, corporate organization, interpersonal and individual. While the decision making process includes several stages namely awareness of needs, information seeking, evaluation of several choices, purchasing and post-purchase evaluation. The information seeking and evaluation process selection stage is a strategic stage for the management of tourism destinations in providing accurate and fast information to tourists.

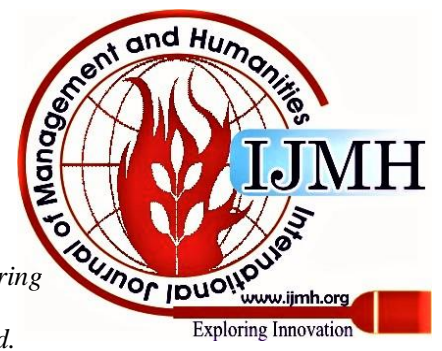




\section{Covid-19 Impact: Indonesia Tourism in New Normal Era}

Because at this stage the tour as a social person is greatly influenced by information not only from the company but also from external companies. Tourist motivation in traveling will depend on tourist behavior.

So that understanding the behavior of tourists in the new normal era is very useful for the management of attractions, as a basis for developing marketing strategies and implementing marketing plans through a marketing mix that includes products, partnerships, people, packaging and programming, places, promotions (Morisson, 2010). Smith and Zook (2011) suggest two actions taken after post-purchase (1) are satisfied, have loyalty and will repurchase, (2) are disappointed and refuse the brand. Therefore, it becomes a necessity for tourism destination management to examine the implications of changing customer behavior, with new paradigms such as the application of health protocols, social distancing and physical distancing, but does not rule out familiarity and hospitality as a characteristic of the tourism industry.

\section{CONCLUSIONS AND RECOMMENDATIONS}

In principle, New Normal is a phase in which Large-Scale Social Restrictions (PSBB) are relaxed and the public is allowed to return to activities with a number of health protocols determined by the government before the discovery of the vaccine.

However, in fact and the results of this research discussion is rather difficult to predict when real tourism will begin to revive because this will largely depend on when the Covid-19 pandemic will end.

What can be conveyed as a conclusion of this research is that all components related to the tourism industry sector must be able to work together to contribute thoughts, steps in innovation, production to start the domestic and international tourist market for the sake of accelerating the direction of tourism in the new normal era.

That there has been a shift in tourist behavior in determining tourist choices will prioritize hygiene, healthy and safety. Furthermore the influence of technology, communication and information in various sectors has changed the shift in travel where digital information will make it easier for prospective tourists to obtain information on planning trips to various tourist attractions. In these conditions all components of the tourism industry both hotels, travel agencies, attractions and various other supports must be able to take alternative cooperation with the digital market place which is a necessity.

\section{REFERENCES}

1. Alegre, Joaquin and Magdalena Caldera. 2009. Analyzing the Effect of Satisfaction and Previous Visits on Tourist Intentions to Return. Emerald European Journal of Marketing. Vol. 43 ISS. 5 or 6 p.670.

2. A.M, Morissan. Integrated marketing communication advertising, Jakarta: Kencana Publisher, 2010.

3. Christine Daymon \& Immy Holloway, Qualitative Research Methods in Public Relations and Marketing Communications, London-New York: Routledge-Taylor \& Francis, 2005.

4. Creswell, John W. Qualitative Inquiry and Research Design: Choosing among Five Approaches, 2nd edition, ThousandOaks-London-New Delhi: Sage Publications, 2007.

5. Kenichi Ohmae, The Next Global Stage: Challenges and Opportunities in Our Borderless World 2005.

6. Klaus Bruhn Jensen \& Nicholas W. Jankowski, A Handbook of Qualitative Methodologies for Mass Communication Research. London \& New York: Routliedge-Taylor \& Francis, 2002.
7. Morgan, Robert M., and Shelby D. Hunt, 1994, "The Commitment-Trust Theory of Relationship Marketing", Journal of Marketing, Vol. 58, July, pp. 20-38.

8. Nashid Golafshani "Understanding Reliability and Validity in Qualitative Research", in the journal The Qualitative Report, volume 8 number 4, December 2003.

9. Philip Kotler, Gary Armstrong, and Geoffrey da Silva, Marketing: An Introduction; An Asian Perspective, Prentice Hall, 2006.

10. Philip Kotler, Hermawan Kartajaya, and Iwan Setiawan, Marketing 4.0: Moving from Traditional to Digital, Wiley, 2017.

11. Smith, PR. and Ze Zook. (2011). Marketing Communications: Integrating offline and online with social media. Great Britain: Ashford Color Press.

12. Tonny Hendratono, Brand Communication as a Strategy to Build Brand Loyalty in the Pariwista Industry in the New Normal Era, Indicatornew.com 2020

13. Zhang, T., and Zou, H. F. 1998. Fiscal Decentralization, Public Spending, and Economic Growth in China. Journal of Public Economics (1998), 67 (2): 221-240

14. https://www.worldometers.info/coronavirus/\#countrie

\section{AUTHORS PROFILE}

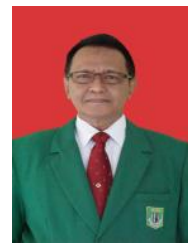

Dr. Eddy Guridno, S.E., M.Si.M., received his doctoral degree in politics from National University, Jakarta, Indonesia. Also bachelor degree and master degree in science management from National University, Jakarta, Indonesia. Director of National Tourism Academy, Jakarta, Indonesia. Assistant Professor in National University, Jakarta, Indonesia.

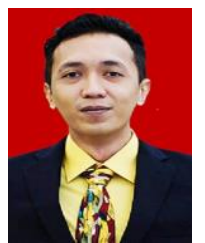

Aberar Guridno, M.AP., received his master degree in public administration from National University, Jakarta, Indonesia. Lecturer assistant who is heading to the assistant professor level. Secretary of Professional Development Board, National University, Jakarta, Indonesia.

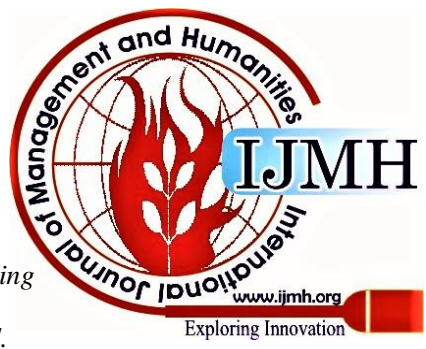

